\title{
Analisis faktor yang berhubungan dengan kejadian hipertensi pada kehamilan di Kota Manado
}

\author{
${ }^{1}$ Yudhaputra Setiadhi \\ ${ }^{2}$ Shirley E. S. Kawengian \\ ${ }^{2}$ Nelly Mayulu
}

\author{
Kandidat Skripsi Fakultas Kedokteran Universitas Sam Ratulangi Manado \\ ${ }^{2}$ Bagian/SMF Gizi Fakultas Kedokteran Universitas Sam Ratulangi Manado \\ Email: yudzsetiadhi@gmail.com
}

\begin{abstract}
Hypertension is a condition where the systolic blood pressure is $>140 \mathrm{mmHg}$ and the diastolic blood pressure is $>90 \mathrm{mmHg}$ measured by a sphygmomanometer. The measurements were performed at least 2 times in a span of one week. Uncontrolled hypertension can cause damage to the arteries, damage to the heart, damage to the brain, kidneys and eyes, as well as accelerating the onset of chronic cardiovascular diseases. Hypertension in pregnancy could affect such things as reduced blood flow to the placenta, fetal growth restriction, premature birth, fetal death, and increased risk of cardiovascular disease. One of the factors that affect the risk of hypertension is a family history of hypertension.The study aimed to see whether there is a relationship between a family history of hypertension and hypertension in pregnancy. The data were collected using crosssectional method. This cross-sectional study was conducted in September-November 2016, in Bahu Public Health Center, Ranotana Public Health Center, Tuminting Public Health Center, Kombos Public Health Center, and Paniki Public Health Center. The sample were taken with total sampling method, with the total number of respondents that are willing around 144 respondent. Based on the research, from 50 respondent with a family history of hypertension, 1 respondent (2\%) belong to the category of stage 1 hypertension, 20 respondent (40\%) belong to the category of pre-hypertension and 29 respondents $(58 \%)$ were normal. Conclusion: Based on the results, it can be deduced that a family history of hypertension mostly did not affect the incidence of hypertension in pregnant woman.
\end{abstract}

Keywords: hypertension, maternal hypertension, family history of hypertension

\begin{abstract}
Abstrak: Hipertensi merupakan keadaan dimana tekanan darah sistolik $>140 \mathrm{mmHg}$ dan tekanan darah diastolik $>90 \mathrm{mmHg}$ yang diukur dengan sphygmomanometer. Pengukuran dilakukan minimal 2 kali dalam rentang waktu 1 minggu. Hipertensi yang tidak terkontrol dapat menyebabkan kerusakan pada pembuluh darah arteri, kerusakan pada jantung, kerusakan pada otak, ginjal dan mata, serta mempercepat terjadinya penyakit kardiovaskular yang kronis. Hipertensi pada wanita hamil dapat mempengaruhi beberapa hal seperti aliran darah ke plasenta berkurang, pertumbuhan janin terhambat, kelahiran prematur, bayi meninggal dalam kandungan, dan meningkatnya risiko terkena penyakit kardiovaskular. Salah satu faktor rikiko yang mempengaruhi hipertensi adalah riwayat hipertensi pada keluarga. Penelitian ini bertujuan untuk melihat apakah ada hubungan antara riwayat hipertensi pada keluarga dan hipertensi pada kehamilan. Pengambilan data dilakukan dengan menggunakan metode cross-sectional. Penelitian cross-sectional ini dilakukan pada bulan September-November 2016 di Puskesmas Bahu, Puskesmas Ranotana, Puskesmas Tuminting, Puskesmas Kombos dan Puskesmas Paniki. Pengambilan sampel dilakukan berdasarkan dengan metode total sampling dengan jumlah responden yang bersedia sebanyak 144 orang. Berdasarkan penelitian didapatkan dari 50 responden dengan riwayat hipertensi pada keluarga 1 responden (2\%) masuk ke dalam kategori hipertensi stadium 1, 20
\end{abstract}


responden (40\%) masuk ke dalam kategori pre-hipertensi dan 29 responden (58\%) yang normal. Simpulan: Berdasarkan hasil tersebut, dapat ditarik kesimpulan bahwa riwayat hipertensi pada keluarga sebagian besar tidak mempengaruhi angka kejadian hipertensi pada ibu hamil

Kata kunci: hipertensi, hipertensi kehamilan, riwayat hipertensi pada keluarga

Hipertensi merupakan manifestasi gangguan hemodinamik sistem kardiovaskular, yang penyebabnya adalah multi faktor sehingga tidak bisa diterangkan dengan hanya satu mekanisme tunggal. ${ }^{1}$ Hipertensi adalah masalah medik yang cukup sering didapatkan pada kehamilan, dengan angka kejadian sekitar 2-4\%. ${ }^{2}$ Gangguan hipertensi pada kehamilan (hypertension pregnancy disorders) merupakan penyebab peningkatan morbiditas dan mortalitas maternal, janin dan neonatus. Wanita hamil dengan hipertensi mempunyai risiko yang tinggi untuk komplikasi yang berat seperti solusio plasenta, penyakit serebrovaskular, gagal organ dan koagulasi intravaskular. ${ }^{2}$

Hipertensi menyebabkan kematian sebanyak 9.4 juta pertahun di seluruh dunia. Pada tahun 2008, di seluruh dunia, sekitar 40 persen dari orang dewasa yang berusia 25 tahun keatas telah didiagnosis dengan hipertensi, jumlah orang yang terkena hipertensi meningkat dari 600 juta pada tahun 1980 menjadi 1 milliar pada tahun 2008. Hipertensi banyak ditemukan di negara - negara yang berpenghasilan rendah dan menengah tidak hanya diakibatkan oleh penghasilan negara tersebut, namun dipengaruhi juga oleh banyaknya penduduk yang tinggal di negara - negara tersebut. Keadaan ini juga dipengaruhi oleh sistem kesehatan yang kurang baik, orang - orang dengan hipertensi yang tidak terdiagnosis, tidak diobati, dan tidak terkendali. ${ }^{3}$ Berdasarkan data Riskesdas 2013 di Indonesia, prevalensi penderita hipertensi adalah 25.8\% terbanyak di Bangka Belitung (30.9\%), diikuti Kalimantan Selatan (30.8\%), Kalimantan Timur (29.6\%), dan Jawa Barat (29.4). ${ }^{4}$ Untuk daerah Sulawesi Utara sendiri, prevalensi penderita hipertensi mencapai $27.1 \%{ }^{4}$
Menurut Guideline dari National Institute for Health and Care Excellence (NICE) pada tahun 2010, gangguan hipertensi selama masa kehamilan membawa risiko untuk ibu dan bayi. Sebuah penelitian di Inggris melaporkan bahwa sepertiga dari kematian ibu hamil adalah akibat dari hipertensi. ${ }^{5}$ Lale Say et. al. melaporkan bahwa hipertensi merupakan faktor risiko nomor dua untuk kematian ibu hamil setelah pendarahan. ${ }^{6}$

Menurut salah satu program dari United Nation yaitu Sustainable Development Goals, dunia telah berhasil membuat langkah yang sangat besar untuk mengurangi angka kematian anak dan meningkatkan kesehatan ibu. Sejak 1990 telah terjadi penurunan lebih dari $50 \%$ kematian anak serta $45 \%$ kematian ibu secara global. $^{7}$

Penelitian ini bertujuan untuk mengetahui hubungan dari faktor-faktor risiko hipertensi pada hipertensi kehamilan.

\section{METODE PENELITIAN}

Desain penelitian yang digunakan ialah penelitian analitik dengan pendekatan cross sectional. Penelitian dilakukan pada bulan september - november 2016 di Puskesmas Bahu, Ranotana, Tuminting, Kombos dan Paniki. Sampel penelitian ini adalah seluruh ibu hamil yang datang atau yang ada dan bersedia di tempat penelitian dalam periode september-november 2016. Variabel penelitian diantaranya Hipertensi kehamilan, dan riwayat hipertensi pada keluarga.

Proseur pengambilan data dimulai dengan survey puskesmas dan rumah sakit untuk menghitung jumlah sampel yang mungkin akan didapatkan dalam rentang waktu penelitian. Setelah memasukan surat permohonnan ijin untuk melakukan penelitian, peneliti akan mendiskusikan 
soal pengambilan data dengan perawat dan bidan yang ada disana. Peneliti akan meninggalkan buku yang sudah dibuat sebagai logbook, dimana perawat atau bidan yang nantinya akan berada di puskesmas atau rumah sakit akan memegang buku itu, dan jika ada pasien ibu hamil datang untuk melakukan pemeriksaan, akan dilakukan pendataan sesuai dengan tabel yang sudah diberikan. Peneliti akan memonitor secara berkala mengenai pengambilan data, dimana peneliti akan memonitor apakah ada ibu yang datang untuk memeriksakan diri. Data yang sudah diambil kemudian akan dianalisis dengan bantuan aplikasi Microsoft Excel dan SPSS.

\section{HASIL PENELITIAN}

Pada penelitian yang dilaksanakan di Puskesmas Bahu, Ranotana, Tuminting, Kombos dan Paniki didapatkan jumlah responden sebanyak 144 orang.

Tabel 1. Distribusi Umur Responden

\begin{tabular}{ccc}
\hline Umur & $\mathbf{n}$ & $\mathbf{( \% )}$ \\
\hline$<20$ & 10 & $7 \%$ \\
$20-25$ & 62 & $43 \%$ \\
$26-30$ & 38 & $26.3 \%$ \\
$31-35$ & 23 & $16 \%$ \\
$36-40$ & 7 & $4.9 \%$ \\
$>40$ & 4 & $2.8 \%$ \\
\hline
\end{tabular}

Usia responden pada rentang umur 2025 memiliki jumlah paling tinggi sebanyak 62 responden (43\%), dan yang paling rendah adalah yang berumur diatas 40 tahun sebanyak 4 responden (2.8\%).

Tabel 2. Distribusi Agama Responden

\begin{tabular}{ccc}
\hline Agama & $\mathbf{n}$ & $\mathbf{( \% )}$ \\
\hline Kristen & 81 & $56.3 \%$ \\
Katolik & 6 & $4.1 \%$ \\
Islam & 55 & $38.2 \%$ \\
Tidak Menjawab & 2 & $1.4 \%$ \\
\hline
\end{tabular}

Berdasarkan agama, responden yang beragama Kristen Protestan ada 81 responden $(56.3 \%)$, beragama Kristen
Katolik ada 6 responden $(4.1 \%)$ dan yang beragama Islam ada 55 responden (36.1\%).

Tabel 3. Distribusi Pendidikan Responden

\begin{tabular}{lcc}
\hline Pendidikan & $\mathbf{n}$ & $\mathbf{( \% )}$ \\
\hline Tamat SD & 5 & $3.5 \%$ \\
Tamat SMP & 29 & $20.1 \%$ \\
Tamat SMA & 91 & $63.2 \%$ \\
Tamat D1/D2/D3 & 17 & $11.8 \%$ \\
Tidak Menjawab & 2 & $1.4 \%$ \\
\hline
\end{tabular}

Pada penelitian didapatkan jumlah terbanyak terdapat pada jenjang pendidikan tamat SMA sebanyak 91 responden $(63.2 \%)$ sedangkan yang paling sedikit adalah yang tamat SD sebanyak 5 responden $(3.5 \%)$.

Tabel 4. Distribusi Pekerjaan Responden

\begin{tabular}{lcc}
\hline Pekerjaan & n & $\mathbf{( \% )}$ \\
\hline Tidak Bekerja & 82 & $56.9 \%$ \\
Sekolah & 4 & $2.8 \%$ \\
Pegawai & 7 & $4.9 \%$ \\
Wiraswasta & 12 & $8.3 \%$ \\
Petani/Nelayan/Buruh & 1 & $0.7 \%$ \\
Lainya & 29 & $20.1 \%$ \\
Tidak Menjawab & 9 & $6.3 \%$ \\
\hline \multicolumn{2}{c}{ Berdasarkan } & hasil
\end{tabular}

didapatkan paling banyak responden tidak bekerja yaitu sebanyak 82 responden $(56.9 \%)$ dan yang paling sedikit yang bekerja sebagai Petani/Nelayan/Buruh yaitu 1 responden $(0.7 \%)$. Responden yang pekerjaannya tidak tercatat di questionaire ada 29 responden $(20.1 \%)$ dan yang tidak memberikan jawaban ada 9 responden $(6.3 \%)$

Tabel 5. Distribusi Jumlah Kehamilan Responden

\begin{tabular}{ccc}
\hline Kehamilan & $\mathrm{n}$ & $(\%)$ \\
\hline 1 & 50 & $34.7 \%$ \\
2 & 53 & $36.8 \%$ \\
3 & 20 & $13.9 \%$ \\
4 & 14 & $9.7 \%$ \\
5 & 5 & $3.5 \%$ \\
Tidak Menjawab & 2 & $1.4 \%$ \\
\hline
\end{tabular}

Menurut data yang didapatkan, paling 
banyak responden sedang dalam kehamilan kedua yaitu sebanyak 53 responden
(36.8\%) dan yang paling sedikit yaitu pada kehamilan ke 5 yaitu 5 responden (3.5\%).

Tabel 6. Distribusi Hipertensi Pada Pasien Berdasarkan Umur

\begin{tabular}{lcccc}
\hline $\begin{array}{l}\text { Umur } \\
\text { (tahun) }\end{array}$ & $\begin{array}{c}\text { Hipertensi } \\
\text { St1 }(\%)\end{array}$ & $\begin{array}{c}\text { Pre-Hipertensi } \\
\mathrm{n}(\%)\end{array}$ & $\begin{array}{c}\text { Normal } \\
\mathrm{n}(\%)\end{array}$ & $\begin{array}{c}\text { Total } \\
\mathrm{n}(\%)\end{array}$ \\
$<20$ & $0(0)$ & $2(1.4)$ & 10 & $12(8.3)$ \\
& & 21 & $(6.9)$ & \\
$20-25$ & $0(0)$ & $(14.6)$ & $40(27.8)$ & $61(42.4)$ \\
& & 17 & & \\
$26-30$ & $0(0)$ & $(11.8)$ & $20(13.9)$ & $37(25.7)$ \\
$31-35$ & $1(0.7)$ & $12(8.3)$ & $10(6.9)$ & $23(16)$ \\
$36-40$ & $0(0)$ & $4(2.8)$ & $3(2.1)$ & $7(4.9)$ \\
$>40$ & $0(0)$ & $2(1.4)$ & $2(1.4)$ & $4(2.8)$ \\
Total & $1(0.7)$ & $58(40.5)$ & $85(59)$ & $144(100)$ \\
\hline St1 sistolik 140-159 diastolik 90-99; Pre HPT sistolik 120-139 diastolik 80-89, Normal sistolik <120 diastolik $>80$.
\end{tabular}

Tabel 7. Distribusi Hipertensi Pada Pasien Berdasarkan Riwayat Hipertensi

\begin{tabular}{lccccc}
\hline Riwayat & \multicolumn{3}{c}{ Hipertensi } & Total & $\begin{array}{c}\mathbf{P} \\
\text { Hipertensi }\end{array}$ \\
\cline { 2 - 4 } & $\begin{array}{c}\text { Hipertensi St1 } \\
\mathrm{n}(\%)\end{array}$ & $\begin{array}{c}\text { Pre-Hipertensi } \\
\mathrm{n}(\%)\end{array}$ & $\begin{array}{c}\text { Normal } \\
\text { N }(\%)\end{array}$ & $\mathbf{N}(\boldsymbol{\%})$ & $(\boldsymbol{\alpha}=(\mathbf{0 . 0 5})$ \\
\hline Ada & $1(0.7)$ & $20(13.9)$ & $29(20)$ & $50(34.6)$ & 0.388 \\
Tidak ada & $0(0)$ & $38(26.5)$ & $56(38.9)$ & $94(65.4)$ & \\
Total & $1(0.7)$ & $58(40.3)$ & $85(59.0)$ & $144(100)$ & \\
\hline
\end{tabular}

Dilihat dari umur, responden yang termasuk kategori hipertensi stadium 1 hanya terdapat di rentang umur 31-35 tahun sebanyak 1 responden $(0.7 \%)$ sedangkan di rentang umur lain tidak terdapat responden yang termasuk di kriteria hipertensi stadium 1. Responden yang termasuk kriteria pre-hipertensi paling banyak berada di rentang umur $20-25$ tahun yaitu sebanyak 21 respoden (14.6\%) dan paling sedikit berada di rentang umur dibawah 20 tahun dan diatas 20 tahun yaitu sebanyak 2 responden (1.4\%) pada setiap rentang umur. Responden yang termasuk kriteria normal paling banyak berada di rentang umur 20-25 tahun yaitu sebanyak 40 responden $(27.8 \%)$ dan yang paling sedikit berada di usia diatas 40 tahun yaitu 2 responden $(1.4 \%)$

Menurut hasil penelitian, responden yang memiliki riwayat hipertensi pada keluarga, terdapat 1 responden $(0.7 \%)$ yang termasuk hieprtensi stadium 1, 20 responden (13.9\%) yang termasuk prehipertensi, dan ada 56 responden (38.9\%) yang normal.

Setelah dilakukan uji statistik antara riwayat hipertensi dan kategori hipertensi pada ibu yang menjadi responden, melalui pengujian Chi-Square didapatkan hasil 0.388. Hasil pengujian statistic ini menyatakan tidak ada hubungan antara riwayat hipertensi dan kategori hipertensi.

\section{BAHASAN}

Penelitian ini memiliki jumlah sampel sebanyak 144 responden dengan distribusi yang memiliki riwayat hipertensi sebanyak $34.6 \%$ dan yang tidak memiliki riwayat hipertensi sebanyak $65.4 \%$. Berdasarkan umur, responden dengan rentang umur 2025 tahun memiliki distribusi tertinggi yaitu $43 \%$, responden berumur diatas 40 tahun memiliki distribusi terendah yaitu $2.8 \%$. 
Berdasarkan tingkat pendidikan, sebanyak $63.2 \%$ responden memiliki pendidikan terakhir SMA, $20.1 \%$ responden memilki pendidikan terakhir SMP, dan $3.5 \%$ responden memiliki pendidikan terakhir SD. Responden yang tamat diploma ada $11.8 \%$ dan yang tidak menjawab ada $1.4 \%$. Responden paling banyak memiliki pekerjaan sebagai wiraswasta yaitu sebanyak $8.3 \%$. Paling sedikit memiliki pekerjaan sebagai petani/nelayan/buruh yaitu sebanyak $0.7 \%$. Jumlah responden yang tidak bekerja ada sebanyak $56.9 \%$.

Hasil dari penelitian ini menunjukan bahwa dari 50 responden $(34.6 \%)$ yang memiliki riwayat hipertensi pada keluarga, terdapat 1 responden (2\%) yang termasuk kategori hipertensi, dan didapatkan 49 responden (98\%) yang tidak termasuk kategori hipertensi. Responden yang tidak termasuk dalam kategori hipertensi, dibagi atas 20 responden $(40 \%)$ yang termasuk pre-hipertensi, dan 29 responden (58\%) yang normal. Hasil penelitian ini tidak sejalan dengan penelitian yang dilakukan oleh Ranasinghe $\mathrm{dkk}^{8}$ dimana terdapat 1951 sampel $(43 \%)$ yang mempunyai riwayat hipertensi pada keluarga dan yang termasuk kategori hipertensi berjumlah 572 sampel $(29.3 \%)$, sedangkan yang tidak masuk kriteria hipertensi sebanyak 1379 (70.7\%). Perbedaan ini diakibatkan karena pada responden peneliti, rata-rata umur responden adalah 26.5 sedangkan pada penelitian yang dilakukan oleh Ranasinghe $\mathrm{dkk}^{8}$, pada sampel yang memiliki riwayat hipertensi rata-rata umur yang didapat yaitu 52.9 dan yang tidak memiliki riwayat hipertensi pada keluarga rata-rata berumur 59.1. Hasil ini sejalan dengan penelitian oleh Carr $\mathrm{dkk}^{9}$, dimana angka terjadinya hipertensi pada kehamilan meningkat sesuai dengan adanya faktor risiko genetik pada keluarga.

Berdasarkan hasil penelitian, didapatkan bahwa dari 94 responden $(65.4 \%)$ yang tidak memiliki riwayat hipertensi pada keluarga, tidak terdapat responden yang termasuk kategori hipertensi. Distribusi 94 responden ini terbagi atas 38 responden $(40.4 \%)$ yang teramasuk pre-hipertensi dan 56 responden (59.6\%) dikategorikan normal. Hasil sesuai dengan penelitian yang dilakukan oleh Ness dkk, ${ }^{10}$ dimana di peneltian tersebut didapatkan hasil bahwa risiko terjadinya hipertensi pada ibu hamil yang tidak memiliki riwayat hipertensi pada keluarga lebih rendah dibandingkan yang memiliki riwayat hipertensi pada keluarga.

Pada hasil penelitian didapatkan pada rentang umur $<20$ dan 21-25 tahun lebih banyak responden yang normal dibandingkan dengan yang pre hipertensi, sedangkan pada rentang umur 26-30, 31$35, \quad 36-40$ dan $>40$ didapatkan yang termasuk kategori pre-hipertensi lebih banyak dari pada yang normal. Hasil ini sesuai dengan penelitian yang dilakukan oleh McNiece $\mathrm{dkk}^{11}$, dimana didapatkan pada dewasa muda lebih sering didapati tekanan darah yang normal daripada yang pre-hipertensi atau hipertensi. Hal serupa juga didapatkan pada penelitian oleh Yadav $\mathrm{dkk}^{12}$, pada penelitian yang dilakukan di india utara didapatkan bahwa prevalensi pre-hipertensi tinggi pada rentang umur 3139 tahun.

Rendahnya jumlah responden yang menderita hipertensi walaupun terdapat riwayat hipertensi yang merupakan salah satu faktor risiko dari hipertensi pada kehamilan $^{8}$ adalah akibat rata-rata usia yang masih rendah, dimana pada usia yang masih rendah, beberapa pemicu hipertensi seperti penyempitan pembuluh darah, penumpukan lemak, masih belum terjadi. ${ }^{13}$

\section{SIMPULAN}

Berdasarkan hasil penelitian yang dilakukan, dapat disimpulkan bahwa tidak didapatkan hubungan antara riwayat hipertensi pada keluarga dan hipertensi pada kehamilan.

\section{SARAN}

Kepada responden yang termasuk kategori hipertensi, disarankan untuk memeriksakan diri lebih lanjut. Untuk responden yang tidak termasuk pada kategori hipertensi untuk mempertahankan kesehatanya, dengan menjaga pola hidup 
dan berolahraga secara rutin. Untuk penelitian selanjutnya, disarankan agar memiliki waktu yang cukup dan jumlah sampel yang besar agar data yang diperoleh dapat lebih baik.

\section{DAFTAR PUSTAKA}

1. Yogiantoro M. Pendekatan klinis hipertensi. Dalam Setiati S, Alwi I, Sudoyo AW, Simadibarata M, Setiyohadi B, Syam AF. Buku ajar ilmu penyakit dalam. Edisi Ke-6. Jakarta Pusat: Interna Publishing; 2014. h. 2259-83

2. Suhardjono. Hipertensi pada kehamilan. Dalam Setiati S, Alwi I, Sudoyo AW, Simadibarata M, Setiyohadi B, Syam AF. Buku ajar ilmu penyakit dalam. Edisi Ke-6. Jakarta Pusat: Interna Publishing; 2014. h. 4005-7

3. World Health Organization. A global brief on hypertension.

WHO/DCO/WHD/2013.2

Switzerland: 2013

4. Badan Penelitian dan Pengembangan Kesehatan Kementrian Kesehatan RI. Riset kesehatan dasar. Jakarta: 2013

5. Hypertension in pregnancy; NICE Clinical Guideline. 2010

6. Say L, Chou D, Gemmill A, Tuncalp O, Moller AB, Daniels J, et al. Global causes of maternal death: a Who systemic analysis. Lancet. 2014:2;e323-33

7. United Nation Development Program. Sustainable development programs. Januari 2016. Diakses dari http://www.undp.org/content/undp/en /home/sustainable-developmentgoals/goal-3-good-health-and-wellbeing.html diakses pada 8 September 2016

8. Ranasinghe P, Cooray DN, Jayawardena R, Katulanda P. The influence of family history of hypertension on disease prevalence and associated metabolic risk factors among Sri Lankan adults. BioMed Central 2015:1-9

9. Carr DB, Epplein M, Johnson CO, Easterling TR, Critchlow CW. A sister's risk: family history as a predictor of pre-eclampsia. Am J Obstet Gynecol. 2005;193:965-72

10.Ness RB, Markovic N, Bass D, Harger G, Roberts JM. Family history of hypertension, heart disease and stroke among woman who develop hypertension in pregnancy. Am J Obstet Gynecol 2003;102:1366-71

11.McNiece KL, Poffenbarger TS, Turner JL, Franco KD, Sorof JM, Portman RJ. Prevalence of hypertension and pre-hypertension among adolescents. The Journal of Pediatrics. 2007:640-4

12.Yadav S, Boddula R, Genitta G, Bhatia V, Bansall B, Kongara S, et al. Prevalence \& risk factors of prehypertension \& hypertension in affluent north indian population. Indian Journal of Medical Research. 2008:712-20

13.Nagase M, Fujita T. Mineralocorticoid receptor activation in obesity hypertension. The Japanese Society of Hypertension. 2009;32:649-57. 